\title{
SIGNIFIKANSI DISIPLIN BELAJAR TERHADAP HASIL BELAJAR MATA PELAJARAN AKIDAH AKHLAK
}

\section{THE INFLUENCE OF LEARNING DISCIPLINE AGAINST STUDENTS AT SUBJECT AQEEDAH MORALS}

\author{
SS Andalucyª, SA Nasution'1, dan H Bisri ${ }^{1}$ \\ 1Program Studi Manajemen Pendidikan Islam, Fakultas Keguruan dan Ilmu Pendidikan, \\ Universitas Djuanda Bogor, Jl. Tol Ciawi No. 1 Kotak Pos 35 Ciawi Bogor 16720 \\ a Korespondensi: Sayu Safira Andalucy, Email: sayu.safira.a@unida.ac.id \\ (Diterima: 11-08-2017; Ditelaah: 12-08-2017; Disetujui: 20-09-2017)
}

\begin{abstract}
The purpose of research to determine whether or not the influence of learning discipline in instructional process of learning outcomes on the subjects of moral aqid. This research used quantitative, associative approach in the form of cause and effect. The sample use of 55 students from the population of 122 students. The data collection technique used multilevel scale questionnaire, observation, interview and documentation. The results showed the significance of regression equation with the result value of Fh25.932 and Ft with dfreg = 1 dfres $=53$ is 4.03 at $5 \%$ level. Thus Fh> Ft (25.932> 4.03) so that Ho is rejected, it means there is a significant influence between the learning discipline with student learning outcomes subjects akidah akhlak. The result of coefficient of determination is $0.5732=0.328$ means that the results of existing in the learning process of students on the subject of moral aqid is $32.8 \%$ influenced by the discipline of learning. While $64.6 \%$ of students' learning achievement subjects akidah akhlak influenced by other factors.
\end{abstract}

Keywords: learning discipline, morals aqeedah, learning outcomes.

\begin{abstract}
ABSTRAK
Tujuan penelitian untuk mengetahui ada atau tidaknya pengaruh disiplin belajar dalam pembelajaran terhadap hasil belajar pada mata pelajaran akidah akhlak. Penelitian ini menggunakan pendekatan kuantitatif, asosiatif berupa sebab akibat. Penggunaan sampel sebanyak 55 siswa dari populasi 122 siswa. Teknik pengambilan hasil data menggunakan angket skala bertingkat, observasi, wawancara dan dokumentasi. Hasil penelitian menunjukkan signifikansi persamaan regresi dengan hasil nilai $F_{\text {hitung } 25.932}$ dan $F_{\text {tabel }}$ dengan $\mathrm{df}_{\text {reg }}=1 \mathrm{df}_{\text {res }}=53$ adalah 4,03 pada taraf $5 \%$. Dengan demikian $\mathrm{F}_{\text {hitung }}>\mathrm{F}_{\text {tabel }}$ (25.932> 4,03 ) sehingga $\mathrm{H}_{0}$ ditolak, artinya terdapat pengaruh yang signifikan antara disiplin belajar dengan hasil belajar siswa mata pelajaran akidah akhlak. Hasil koefisien determinasi yaitu $0.573^{2}=0.328$ artinya hasil yang ada dalam proses belajar siswa pada mata pelajaran akidah akhlak sebesar $32.8 \%$ dipengaruhi oleh disiplin belajar. Sedangkan $64.6 \%$ hasil belajar siswa mata pelajaran akidah akhlak dipengaruhi oleh faktor lain.
\end{abstract}

Kata kunci: akidah akhlak, disiplin belajar, hasil belajar.

Andalucy SS, SA Nasution, dan H Bisri. 2017. Signifikansi disiplin belajar terhadap hasil belajar mata pelajaran akidah akhlak. Tadbir Muwahhid1(2): 116-127. 


\section{PENDAHULUAN}

Belajar adalah sebuah bagian yang tidak akan mungkin dipisahkan dari kegiatan pada proses pencarian ilmu dalam satu lembaga pendidikan. Belajar tidak hanya sebatas

mengumpulkan pengetahuan,melainkan sebuah perkembangan kejiwaan pada diri seseorang, akibatnya lahirlah perubahan akhlak ataupun karakter. Perubahan dari belajar ada yang tersimpan pada individu siswa yang tak diwariskan secara genetik. Perubahan itu terjadi pada pemahaman, persepsi, perilaku serta motivasi sebagai akibat pengalaman dari setiap keadaan yang tertentu. Proses kegiatan perkembangan kejiwaan dapat disebabkan adanya interaksi seseorang terhadap lingkungan (Sanjaya 2010).

Proses dalam aktivitas pembelajaran merupakan interaksi pendidik dengan siswa pada pencapaian sebuah orientasi dalam pembelajaran, yaitu untuk tercapainya keberhasilan pembelajaran yang mencakup tingkah laku, pencapaian kemampuan seusai menyelesaikan kegiatan pembelajaran. Berhasil ataupun tidak pada proses aktivitas pembelajaran bisa terdeteksi dari perolehan hasil akhir siswa pada aktivitas belajar. Hasil kegiatan belajar maksudnya berubahnya sikap serta tingkahlaku yang positif serta kemampuan dalam individu pada suatu proses aktivitas belajar mengajar. Prestasi belajar diikuti keberhasilan dalam pendidikan, sebab itu perolehan hasil pembelajaran memiliki fungsi sebagai indikator atas penguasaan pengetahuan.

Mata pelajaran Akidah Akhlak tujuannya supaya siswa lebih mengenal, memahami, menghayati dan tentunya memiliki keimanan kepada Allah SWT serta diimplementasikan dalam akhlak karimahpada aktivitas yang dijalani kesehariannya melalui aktivitas pemberian arahan, pemberian pembelajaran dan latihan. Keberhasilan pembelajaran Akidah Akhlak terlihat pada hasil belajar kognitif, afektif serta psikomotorik. Perolehan hasil belajar ditentukan faktor internal serta faktor eksternal. Faktor internal dipengaruhi oleh hasil pembelajaran adalah disiplin belajar.

Disiplin pada kegiatan belajar menjadi suatu kegiatan penting yang seharusnya ada padasiswa, karena dengan penanaman dan pelaksanaan disiplin dalam aktivitas belajar, siswa akan seoptimal mungkin melaksanakan aktivitas belajar. Disiplin belajar ditentukan oleh keberhasilan siswa pada pelaksanaan proses belajarnya, dengan tidak adanya disiplin tidak akan ada koordinasi dan kerjasama diantara guru sertasiswa sehingga mengakibatkan aktivitas belajar ternyata tercapai dengan kurang optimal.

Disiplin merupakan pelatihan yang mampu memberikan hasil pada suatu karakter atau perilaku khusus yang mampu melahirkan perkembangan moral, fisik serta mental untuk tujuan yang diharapkan.Di sekolah, kedisiplinan banyakdipakai dalam melaksanakan kontrol pada perilaku individu siswa yang diinginkan supaya penugasan sekolah mampu berjalan secara optimal (Yamin 2013).

Ada empat jenis disiplin utama pada individu siswa dalam satu lembaga pendidikan, yaitu disiplin ketika memakai pakaian, disiplin berpenampilan, disiplin ketika waktu belajar serta disiplin lingkungan. Kedisiplinan dalam pembelajaran siswa di antaranya ketepatan waktu masuk kelas, kelengkapan peralatan belajar, ketepatan waktu menyelesaikan tugas dan pekerjaan rumah, selalu mengikuti pelajaran, besarnya sebuah 
perhatian ketika guru melakukan proses penjelasanserta tidak meninggalkan kelas sebelum waktunya.

Lembaga Pendidikan Madrasah Aliyah Miftahul Huda masih memiliki siswa dengan tingkat rendah dalam kedisiplinan. Ada kesesuaian dengan yang dinyatakan dari pesan yang didapat ketika wawancara dengan Kepala Madrasah Aliyah Miftahul Huda, juga sebagai guru dalam mata pelajaran Akidah Akhlak yaitu rendahnya kedisiplinan siswa. Sekitar 15\% dari 122 siswa masih terlambat mengumpulkan tugas, 25\% dari 122 siswa dengan ketidaktepatan kehadiran dikelas serta keluar kelas apabila sedang tidak ada guru dalam kelas dan sekitar 20\% dari 122 siswa tidak memperhatikan guru ketika sedang mengajar. Berdasarkan hasil wawancara, ntuk hasil belajar Akidah Akhlak, sekitar 25\% dari 122 siswa dengan tingkat perolehan evaluasi pada belajar sangat rendah. Melihat fenomena diatas, penting dilakukan penelitian tentang "pengaruh disiplin belajar terhadap hasil belajar mata pelajaran akidah akhlak."

\section{MATERI DAN METODE}

\section{Materi}

\section{Disiplin Belajar}

Disiplin merupakan tertibnya keadaan dalam suatu organisasi, setiap individu dengan senang hati melaksanakan ketentuan hasil dari persetujuan bersama serta disepakati. Disiplin adalah perolehan pada waktu diberikannya arahan atas apa yang menjadi keinginan serta kepentingan dalam mencapai perolehan tindakan yang efektif. Akhirnya dapat dinyatakan bahwa disiplin belajar sebagai perilaku siswa yang menunjukkan satu bentuk ketaatan, peraturan yang dipatuhi, pelaksanaan tata tertib serta norma (Imron 2012).

Disiplin menjadi sesuatu yang begitu penting untuk individu siswa. Oleh karena itu, penanaman kedisiplinan harus dilakukan kepada individu siswa secara berkesinambungan, agar menjadi terbiasa. Menurut Ali Imron yang mengutip pendapat The Liang Gie, mengatakan bahwa, "disiplin merupakan tata tertib pada suatu organisasi dimana setiap individu-individu mengikuti peraturan-peraturan yang sudah disepakati dengan senang hati" (Imron 2012).

Islam memberikan penjelasan untuk selalu konsisten terhadap peraturan Allah SWT. Ini sangat sesuai dengan firman Allah SWT surat Huud ayat 112, yang artinya "Maka tetaplah engkau (Muhammad) di jalan yang benar, sebagaimana telah diperintahkan kepadamu dan (juga) orang yang bertaubat bersamamu, dan janganlah kamu melampaui batas. Sungguh Dia Maha Melihat apa yang kamu kerjakan" (Departemen Agama RI Al-Qur'an dan Terjemahnya 2004)

Disiplin merupakan sebuah ketaatan individu pada saat melaksanakan aturan yang didorong akan hadirnya sebuah kesadaran yang ada dalam hatinya. Disiplin belajar yaitu perilaku siswa dalam menunjukkan kepatuhan terhadap semua aturan karena terdorong adanya sebuah kesadaran melaksanakan tujuan belajar yang diinginkan (Prihatin 2011).

Perintah perilaku disiplin tertulis dalam firman Allah SWT surat An-Nisa' ayat 103, yang menjelaskan tentang shalat sebagai implementasi sebuah pelatihan untuk melakukan pembinaan kedisiplinan. Pelaksanaan shalat pada awal waktu dan tepat waktunya dapat menimbulkan tumbuhnya kebiasaan secara efektif, teratur serta berkesinambungan menunaikan shalat pada waktu yang sudah ditentukan. Siswa 
perlu memberikan penanaman sikap disiplin dalam hal belajar.Semuanya menjadi kebiasaan yang baik dan muncul dalam diri siswa tersebut. Siswa juga perlu memberikan perhatian kedisiplinan pada waktu belajar di sekolah guna mampu belajar secara teratur, sehingga memperoleh hasil yang baik.

Disiplin siswa di sekolah diantaranya ada empat macam,yaitu disiplin berpakaian, disiplin berpenampilan, disiplin pada aktivitas belajar dan disiplin lingkungan.Disiplin belajar yaitu aplikasi dari kedisiplinan yang dilakukan siswa di sekolah. Disiplin belajar meliputi : disiplin dalam waktu, disiplin dalam penegakkan aturan dan disiplin sikap. Aspek disiplin belajar yaitu ketaatan pada waktu kehadiran belajar, taatnya siswa terhadap penugasan pelajaran, ketaatan dalam menggunakan fasilitas belajar dan adanya ketaatan pada aktivitas belajar di satu lembaga pendidikan (Syafruddin 2005).

Kedisiplinan pada individu siswa sangatlah berbeda-beda. Ada yang memiliki disiplin dalam belajar tinggi serta yang memiliki disiplin dalam belajar yang rendah.Kedisiplinan siswa terpengaruhi oleh adanya faktor yang muncul dari dalam juga dari luar, diantaranya yaitu individu siswa, sikap pendidik, lingkungan dan faktor tujuan.

\section{Hasil Belajar Siswa}

Dalam Kamus Besar Bahasa Indonesia hasil yaitu sesuatu yang diadakan oleh usaha. (Departemen Pendidikan Nasional KBBI, 2008). Saat manusia melaksanakan sebuah usaha dalam proses mengajar anak didiknya pastilah sudah pula melaksanakan usaha menilai hasil usaha yang sudah dilaksanakanketika mendidikanak tersebut. Kendatipun menggunakan bentuk serta metode sederhana (Suryabrata 1998).
Hasil belajar yaitu hasil kemampuan yang didapatkan siswa sesudah melalui aktivitas pembelajaran. Hasil belajardiartikan berubahnya sikap yang relative permanent dalam individu yang melakukan aktivitas belajar, adanya bentuk perubahan diharapkan adalah perubahan baik serta posiitif. Hasil belajar dapat dinyatakan sebagai bentuk perubahan yang ada pada individu siswa, baik yang menyangkut aspek pengetahuan, sikap serta keterampilan sebagai hasil aktivitas belajar (Jihad 2012).

Adapun hasil pada aktivitas belajar yang ditekankan yaitu hasil belajar pada mata pelajaran akidah akhlak, yang menjadi mata pelajaran agama Islam di Madrasah Aliyah. Standar Kompetensi mata pelajaran akidah akhlak di lembaga pendidikan Madrasah Aliyah yaitu proses penanaman akidah dalam bentuk pemberian, pemupukan dan pengembangan pengetahuan, penghayatan, pengamalan, proses pembiasaan, juga pengalaman yang didapatkan siswa tentang akidah akhlak Islam sehingga menjadi individu yang akan bertambah keyakinan dan ketakwaannya kepada Allah SWT, juga melahirkan individu yang memiliki akhlak yang mulia dan terjauhkan dari akhlak yang tidak terpuji pada kehidupan sehari-hari, melalui proses perjalanan hidup individu maupun kehidupan sosial, sebagai implementasi atas apa yang diajarkan serta nilai yang ada dalam akidah Islam (Djazimi 2016).

Hasil belajar merupakan objek evaluasi dari proses belajar, sebagai suatu hasil dalam proses mengajar guru dan belajar siswa. Supaya tahu berhasilnya aktivitas belajar siswa, sekiranya perlu ada informasi terkait dengan terlihatnya perubahan perilaku serta sikap siswa.Benyamin Bloom mengemukakan hasil aktivitas belajar pada tiga ranah, yakni ranah pengetahuan, ranah 
sikap dan ranah keterampilan (Sudjana 2009).

Ranah kognitif merupakan perolehan dari hasil yang dilakukan dalam belajar, yang berkenaan dengan kapasitas nalar otak atau intelegensi. Ranah kognitif ada enam, yaitu pengetahuan, adanya pemahaman, adanya analisis, sintesis dan evaluasi. Didalamnya terdapat aspek pengetahuan tingkat rendah serta aspek pengetahuan tingkat tinggi. Pengukuran berhasilnya siswa berdasarkan ranah kognitif, guru dapat melaksanakan evaluasi produk, yaitu dengan mengadakan berbagai macam tes, baik lisan ataupun tertulis. Dalam pembelajaran pada umunya tes diselenggarakan dengan bermacam-macam bentuk ulangan, seperti penilaian harian, penilaian semester maupun penilaian umum (Danim 2013).

Ranah afektif berkenaan dengan sifat dan nilai. Hasil belajar afektiftergambarkan dari tingkahlaku siswa, misalnya bentuk perhatian yang diberikan siswa terhadap pelajaran, munculnya keinginan dalam belajar, memberi penghargaan kepada guru juga teman sekelas, pembiasaan dalam aktivitas belajar dan hubungan sosial. Ada berbagai macam kriteria ranah afektif sebagai hasil belajar, kriterianya mulai pada tingkat dasar atau sederhana menuju tingkat yang kompleks, yaitu receiving (penerimaan), responding (jawaban), valuing (penilaian), organizing (organisasi) dan karakteristik nilai (Sudjana 2009).

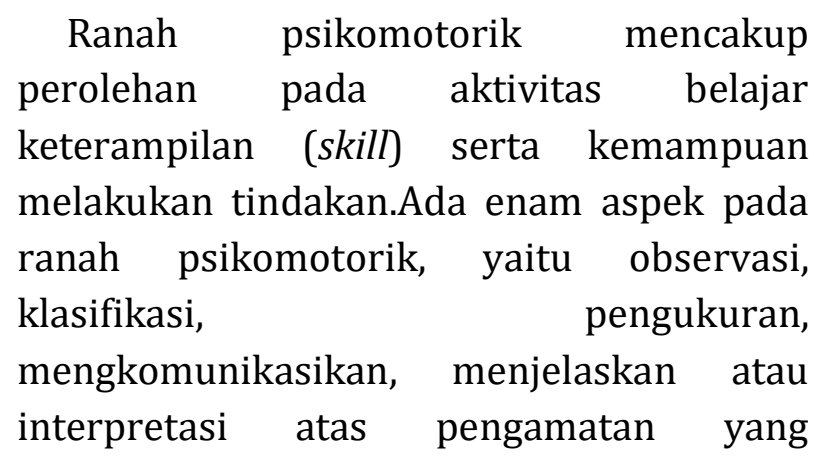

dilakukan dan melakukan eksperimen (Sudjana 2009).

Keberhasilan dalam belajar dipengaruhi oleh faktor internal serta faktor eksternal. Faktor internal adalah faktor yang sumbernya ada pada diri siswa yang mampu mempengaruhi hasil belajarnya. Faktor internal yaitu: kecerdasan, minat serta perhatian, ketekunan, kedisiplinan, motivasi belajar, kebiasaan belajar, sikap, keadaan jasmani serta kesehatan. Adapun faktor eksternal asalnya muncul pada siswa yang berasal dari luar dirinya yang mempengaruhi hasil belajarnya, yaitu lingkungan dalam keluarga, lingkungan dalam sekolah dan lingkungan masyarakat. Keadaan keluarga berpengaruh atas hasil belajar siswa. Keluarga yang keadaan ekonominya rendah, pertengkaran antara orang tuanya, tidak adanya fokus perhatian dari orang tua pada anaknya, serta kebiasaan berperilaku tidak baik sehari-hari orang tua, akan berpengaruh atas perolehan hasil pada belajar siswa. Ahmad Susanto mengemukakan bahwa sekolah memiliki kontribusi besar yang ikut menentukan hasil belajar siswa. Semakin tinggi kemampuan belajar yang muncul dalam individu siswa serta pengajaran yang berkualitas di sekolah, hasil belajarpun akan semakin tinggi. Kualitas dalam aktivitas pembelajaran di sekolah dipengaruhi oleh guru. Berdasarkan pendapat ini dapat ditegaskan bahwa adanya faktor eksternal yang sangat berperan mempengaruhi hasil belajar siswa adalah guru (Susanto 2013).

Belajar yakni proses yang akan dirasakan seumur hidup oleh semua orang, sejak dalam kandungan sampai ajal tiba. Menuntut ilmu menjadi kewajiban setiap muslim, baik laki-laki juga perempuan yang harus dijalani sepanjang perjalanan hidupnya. Rasulullah SAW bersabda yang artinya "menuntut ilmu wajib bagi setiap 
muslim (baik muslimin maupun muslimah)" HR. Ibnu Majah (Wahyudin 2016).

Menuntut ilmu adalah wajib untuk muslimin, baik laki-laki juga perempuan yang dilalui sepanjang perjalanan hidupnya. Amat berartinya belajar, terutama menuntut ilmu.Di dalam Al-Qur'an dan Hadits banyak dijelaskan mengenai pentingnya arti belajar.Islam bukan saja mencukupkan pada anjuran supaya belajar saja, tetapi juga menganjurkan supaya seseorang itu harus terus belajar, sekalipun telah mencapai puncaknya serta adanya perintah agar selalu memanjatkan permohonan (berdo'a) diiringi ikhtiar untuk mendapatkan ilmu pengetahuan.

Belajar adalah kegiatan jiwa seseorang saat melakukan aktivitas interaksi dengan lingkungan sekitarnya sehingga menghasilkan sikap serta perilaku yang mengalami perubahan bersifat positif, baik perubahan dalam aspek pengetahuan, sikap serta keterampilan (Sanjaya 2010).

Belajar memiliki makna perubahan pada perilaku hasil dari pengalamanmasa lalu ataupun dari kegiatan pembelajaran yang direncanakan. Sehingga dapat diambil intisari dari belajar yaitu suatu aktifitas mental (psikis) dalam interaksi bersama lingkungannya yang menghasilkan perubahan yang bersifat relatif konstan dapat melalui sebuah pengalaman ataupun pembelajaran yang direncanakan. Tandanya seseorang sudah melaksanakan kegiatan belajar yaitu berubahnya sikap ataupun tingkahlaku, terdiri dari perubahan yang bersifat pengetahuan (kognitif), nilai dan sikap (afektif) maupun keterampilan (psikomotorik).

\section{Metode}

Pendekatan yang digunakan dalam penelitian yaitu pendekatan penelitian kuantitatif. Penelitian kuantitatif yang dipakai ketika mencari jawaban atas permasalahan yang diteliti melalui teknik pengukuran yang tepat terhadap variabelvariabel tertentu, sehingga kesimpulannya dapat digeneralisasikan (Arifin 2012).

Pendekatan kuantitatif sangat mungkin dilaksanakannya pencatatan yang memiliki bentuk angka dan analisis menggunakan statistik. Selain itu pendekatan ini digunakan dalam meneliti permasalahan yang sudah jelas, data mampu diamati serta dapat diukur, peneliti bermaksud melaksanakan uji hipotesis dan generalisasi (Supardi 2012).

Jenis penelitian menggunakan korelasi kausal memiliki tujuan supaya diketahui pengaruh variabel disiplin belajar terhadap variabel hasil belajar mata pelajaran Akidah Akhlak. Alat analisis menggunakan analisis regresi. Metode regresi ini digunakan utuk mengetahui bagaimana antar variabel saling berhubungan (Supardi 2012).

Teknik pengumpulan data memakai skala likert, dokumentasi, wawancara, serta observasi. Teknik analisis data yaitu statistik inferensial, Sugiono menuturkan bahwa statistik inferensial dipakai untuk menganalisis data pada sampel, lalu hasilnya dapat digunakan untuk populasi (Sugiono 2013).

Analisis data bertujuan untuk membuktikan apakah ada pengaruh disiplin belajar terhadap hasil belajar siswa yang meliputi korelasi product moment, persamaan regresi, mencari signifkansi persamaan regresi dan koefisien determinasi.Korelasi product moment dipakai guna mengetahui apakah ada hubungan variabel $X$ (disiplin belajar) dan variabel Y (Hasil Belajar). Dengan keputusan yang diambil jika nilai signifikansi $<0.05$ maka terdapat korelasi dan sebaliknya apabila nilai signifikansi $>$ 0.05 maka tidak terdapat korelasi. 
Penelitian ini dilaksanakan di Madrasah Aliyah Miftahul Huda yang beralamat di Jl. Raya Puncak Megamendung No. 64 Cipayung Girang, Kecamatan Megamendung, Kabupaten Bogor, Provinsi Jawa Barat.

Populasi yang menjadi objek adalah seluruh siswa MA Miftahul Hudda Cipayung Bogor tahun ajaran 2016/2017 yang berjumlah 122 siswa yang tersebar dalam tiga kelas, kelas X sebanyak 49 siswa, kelas XI berjumlah 40siswa dan kelas XII sebanyak 33 siswa. Sampel yang dipakai yaitumenggunakan jumlah sampel dengan taraf kesalahan $0,10 \quad(10 \%)$. Dengan demikian sampel yang akan diteliti adalah sebanyak 55 siswa, adapun cara menentukan sampel yaitu menggunakan rumus Slovin.

\section{HASIL DAN PEMBAHASAN}

\section{Hasil}

\section{Deskripsi Data Variabel Disiplin Belajar}

Dalam penelitian ini, peneliti memperoleh data variabel mengenai disiplin belajar dengan menggunakan angket berupa skala bertingkat.Angket disiplin belajar diberikan kepada 55 responden dengan jumlah 16 butir pernyataan. Hasil analisis statistik deksriptif variabel disipilin belajar yang dapat dilihat pada tabel 1 .

Tabel 1 Analisis statistik deskriptif variabel disiplin belajar

\begin{tabular}{lrrrrrr}
\hline & $\mathrm{N}$ & Min & Max & Sum & Mean & $\begin{array}{l}\text { Std. } \\
\text { Dev }\end{array}$ \\
\hline $\mathrm{X}$ & 55 & 59 & 78 & 3751 & 68.20 & 4.152 \\
\hline
\end{tabular}

Dari analisis tabel 1 diatas diperoleh skor terendah 59, skor tertinggi 78, mean 68.20 dan standar deviasi atau simpangan baku sebesar 4.15. Untuk menentukan kualifikasi disiplin belajar, dengan penentuan kelas dikategorikan menjadi 3, yaitu sedang, baik dan baik sekali, yang dapat dilihat pada tabel 2 tentang persentase disiplin belajar.

Tabel 2 Persentase disiplin belajar

\begin{tabular}{lcrll}
\hline Interval & F & Persentase & Keterangan & Kualitas \\
\hline $59-65$ & 17 & $30,9 \%$ & Sedang & \\
$66-72$ & 29 & $52,73 \%$ & Baik & Baik \\
$73-79$ & 9 & $16,37 \%$ & Baik Sekali & \\
Jumlah & 55 & $100 \%$ & & \\
\hline
\end{tabular}

Pada tabel 2 terlihat bahwa sebanyak 29 responden $(52,73 \%)$ memiliki kategori baik, lalu 17 responden (30,9\%) memiliki kategori sedang dan 9 responden $(16,37 \%)$ memiliki kategori baik sekali.

\section{Deskripsi Data Variabel Hasil Belajar}

Hasil belajar siswa diperoleh dari sampel 55 siswa yang diambil secara acak dengan menggunakan teknik dokumentasi yang diambil dari nilai raport siswa tahun pelajaran 2016-2017 semester ganjil, dengan data pada tabel 3 .

Tabel 3 Analisis Statistik Deskriptif Variabel Hasil Belajar

\begin{tabular}{lrrrrrr}
\hline & N & Min & Max & Sum & Mean & $\begin{array}{l}\text { Std. } \\
\text { Dev }\end{array}$ \\
\hline $\mathrm{X}$ & 55 & 80 & 88 & 4564 & 82.98 & 2.095 \\
\hline
\end{tabular}

Analisis variabel hasil belajar siswa diperoleh skor terendah 80, skor tertinggi 88, mean 82,98 dan simpangan baku 2,095. Sehingga hasil belajar siswa dalam mata pelajaran Akidah Akhlak dapat disimpulkan dalam kategori baik.

\section{Pengujian Prasyarat Analisis Data}

Pengujian prasyarat analisis data yang digunakan yaitu uji normalitas yaitu 
menggunakan uji liliefors, dan uji linearitas. Pengujian normalitas diperlukan supaya diketahui apakah data variabel $\mathrm{X}$ dan $\mathrm{Y}$ beristribusi normal atau berdistribusi tidak normal, dengan keputusan pengujian taraf signifikan 0,05 dan hipotesisnya yaitu, jika Lhitung $<$ Ltabel, maka data tersebut memiliki populasi yang terdistribusi normal, dan jika Lhitung> Ltabel, maka data penelitian berasal dari populasi yang tidak terdistribusi normal. Adapun hasil pengujian liliefors variabel disiplin belajar yakni Lhitung $<$ Ltabel
$(0,0117<0,1194)$, maka $\mathrm{H}_{0}$ ditolak, artinya data merupakan populasi terdistribusi normal. Uji liliefors selanjutnya untuk variabel hasil belajar, dengan hasil Lhitung< Ltabel $(-0,0082<0,1194)$, maka $\mathrm{H}_{0}$ ditolak berarti data berasal dari populasi berdistribusi normal.

\section{Uji Normalitas}

Adapun uji normalitas pada variabel disiplin belajar menghasilkan data yang diuraikan pada Tabel 4.

Tabel 4 Uji normalitas liliefors variabel disiplin belajar



a. Lilliefors Significance Correction; *. This is a lower bound of the true significance.

Berdasarkan Tabel 4, terlihat nilai sig. dilihat melalui Tabel 5. Berdasarkan Tabel 5, variabel disiplin belajar sebesar 0,200, karena nilai sig. Menunjukkan lebih dari terlihat sig. variabel hasil belajar sebesar 0,05 , sehingga menunjukkan adanya hubungan yang signifikan, artinya data berdistribusi normal. Sedangkan untuk uji 0,60 artinya dapat disampaikan bahwa data variabel hasil belajar adalah data berdistribusi normal, karena nilai sig. lebih normalitas variabel hasil belajar dapat besar dari 0,05.

Tabel 5 Uji normalitas liliefors variabel hasil belajar

Tests of Normality

\begin{tabular}{|c|c|c|c|c|c|c|}
\hline & \multicolumn{3}{|c|}{ Kolmogorov-Smirnova } & \multicolumn{3}{|c|}{ Shapiro-Wilk } \\
\hline & Statistic & $\mathrm{df}$ & Sig. & Statistic & Df & Sig. \\
\hline Y & .117 & 55 & .060 & .937 & 55 & .006 \\
\hline
\end{tabular}

a. Lilliefors Significance Correction

\section{Uji Linearitas}

Pengujian linearitas diperlukan untuk menguji model persamaan regresi variabel
$\mathrm{Y}$ atas variabel $\mathrm{X}$, dan untuk mengetahui hubungan kelinieran kedua variable. Uji linearitas memakai regresi sederhana disajikan pada Tabel 6. 
Tabel 6 Hasil perhitungan uji linearitas

\begin{tabular}{|c|c|c|c|c|c|c|}
\hline \multicolumn{7}{|c|}{ ANOVA Table } \\
\hline \multirow{4}{*}{$\mathrm{X}^{*} \mathrm{Y}$ Between Group } & & Sum of Squares & $\mathrm{df}$ & Mean Square & $\mathrm{F}$ & Sig. \\
\hline & (Combined) & 356.324 & 7 & 50.903 & 4.165 & .001 \\
\hline & Linearity & 305.798 & 1 & 305.798 & 25.018 & .000 \\
\hline & Deviation from Linearity & 50.526 & & 8.421 & .689 & .659 \\
\hline Within Groups & & 574.476 & & 12.223 & & \\
\hline Total & & 930.800 & 54 & & & \\
\hline
\end{tabular}

Pada tabel 6 ditentukan bahwa signifikansi sebesar 5\% $(0,05)$, artinya nilai sig linearity $(0,000)<$ nilai signifikansi $(0,05)$, dan sig deviation from linearity $(0,659)>\alpha \quad(0,05)$. Berdasarkan dua pernyataan itu, maka disimpulkan bahwa variabel disiplin belajar memiliki hubungan linear dan signifikan dengan hasil belajar siswa.

\section{Penguj ian Hipotesis Statistika}

Pengujian hipotesis statistika bertujuan untuk membuktikan keberadaan pengaruh disiplin belajar terhadap hasil belajar siswa. Pengujian hipotesis statistika diantaranya korelasi product moment, persamaan regresi, signifikansi persamaan regresi serta koefisien determinasi.

\section{Korelasi Product Moment}

Korelasi product moment digunakan dalam upaya mengetahui keberadaan hubungan antara variabel X dan Y. Dasar pengambilan keputusan, jika nilai $r_{\text {hitung }}>r_{\text {tabel }}$ maka terdapat korelasi, apabila $r_{\text {hitung }}<r_{\text {tabel }}$ maka tidak terdapat korelasi. Adapun nilai korelasi product moment dapat dilihat pada Tabel 7.
Pada tabel 7 dijelaskan bahwa penggunaan korelasi product moment mendapatkan $r_{\mathrm{xy}}=0,573$ dan $\mathrm{r}_{\text {tabel }}$ untuk $\mathrm{N}=55$ dan taraf signifikansi $5 \%$ yaitu $\mathrm{r}=$ 0,266 . Dengan demikian $r_{\text {hitung }}>r_{\text {tabel }}(0,573$ $>0,266)$. Maka, $\mathrm{H}_{0}$ ditolak artinya yaitu terdapat korelasi signifikan antara disiplin belajar dan hasil belajar siswa.

Tabel 7 Korelasi product moment

\begin{tabular}{lcc}
\hline \multicolumn{3}{c}{ Correlations } \\
\hline & X & \multicolumn{1}{c}{ Y } \\
\hline X Pearson Correlation & 1 & $.573^{* *}$ \\
Sig. (2-tailed) & & .000 \\
N & 55 & 55 \\
Y Pearson Correlation & $.573^{* *}$ & 1 \\
Sig. (2-tailed) & .000 & \\
N & 55 & 55 \\
\hline **Corelation is significant at the 0.01 & level (2- \\
1tailed). &
\end{tabular}

\section{Persamaan Regresi}

Analisis regresi yang dipakaiadalah analisis regresi sederhana, yang berorientasi bagaimana diketahui pengaruh disiplin belajar terhadap hasil belajar siswa yang akan disajikan pada tabel 8 . 
Tabel 8 Persamaan regresi

\begin{tabular}{|c|c|c|c|c|c|}
\hline \multicolumn{6}{|c|}{ Coefficients $^{\mathrm{a}}$} \\
\hline \multirow{2}{*}{ Model } & \multicolumn{2}{|c|}{ Unstandardized Coefficients } & Standardized Coefficients & \multirow{2}{*}{$\mathrm{T}$} & \multirow{2}{*}{ Sig. } \\
\hline & B & Std. Error & Beta & & \\
\hline 1 (Constant) & 63.257 & 3.880 & & 16.302 & .000 \\
\hline $\mathrm{X}$ & .289 & .057 & .57 & 5.092 & .000 \\
\hline
\end{tabular}

a. Dependent Variable: $\mathrm{Y}$

Pada tabel 8, analisis uji regresi sederhana diperoleh nilai konstanta (a) 63,257 dan nilai konstanta (b) 0,289, maka persamaan regresi yaitu $\hat{Y}=63,257+0,289$ $\mathrm{X}$ karena nilai koefisien (b) bertanda positif $(0,289)$ dapat dikatakan hubungan antara disiplin belajar dengan hasil belajar merupakan hubungan yang berbanding lurus. Artinya semakin tinggi disiplin belajar, semakin tinggi pula hasil belajar Tabel 9 Signifikansi persamaan regresi siswa, adapun jumlah setiap tingkatan ketika ditambah yaitu sebesar 0,289.

\section{Signifikansi Persamaan Regresi}

Setelah uji analisis regresi, diteruskan dengan uji signifikansi persamaan regresi. Kriteria pengujian uji analisis regresi adalah $\mathrm{H}_{0}$ dierima jika $\mathrm{F}_{\text {hitung }}<\mathrm{F}_{\text {tabel }}$ dan $\mathrm{H}_{0}$ ditolak jika $F_{\text {hitung }}>F_{\text {tabel. }}$ Dapat dilihat pada tabel 9.

ANOVA ${ }^{b}$

\begin{tabular}{llrrrrr}
\hline \multicolumn{1}{c}{ Model } & Sum of Squares & Df & Mean Square & F & \multicolumn{1}{c}{ Sig. } \\
\hline 1 Regression & 77.856 & 1 & 77.856 & 25.932 & $.000^{\text {a }}$ \\
Residual & 159.126 & 53 & 3.002 & & \\
Total & 236.982 & 54 & & &
\end{tabular}

a. Predictors: (Constant), X; b. Dependent Variable: $Y$

Berdasarkan table 9, diperoleh adalah nilai $F_{\text {hitung }} 25,932$ dan $F_{\text {tabel }}$ dengan $\mathrm{df}_{\text {reg }}=1$, $\mathrm{df}_{\text {res }}=53$ adalah 4,03 pada taraf 5\%. Dengan demikian, $F_{\text {hitung }}>F_{\text {tabel }}(25,932>4,03)$, sehingga $\mathrm{H}_{0}$ ditolak dan disimpulkan terdapat pengaruh yang signifikan antara disiplin belajar terhadap hasil belajar siswa.

\section{Koefisien Determinasi}

Berdasarkan Tabel 10, diperoleh perhitungan korelasi antara disiplin belajar dengan hasil belajar sebesar 0,573 dengan koefisien determinansi sebesar 0,328. Dengan demikian terdapat hubungan yang positif antara disiplin belajar dengan hasil belajar siswa, yaitu meningkatnya disiplinan belajar diikuti oleh meningkatnya hasil belajar.

Tabel 10 Koefisien determinasi

Model Summary

\begin{tabular}{lllll}
\hline Model & $\mathrm{R}$ & $\begin{array}{c}\mathrm{R} \\
\text { Square }\end{array}$ & $\begin{array}{c}\text { Adjusted } \\
\text { R Square }\end{array}$ & $\begin{array}{c}\text { Std. Error } \\
\text { of the } \\
\text { Estimate }\end{array}$ \\
\hline 1 & $.573^{\mathrm{a}}$ & .328 & .316 & 1.733
\end{tabular}

a. Predictors: (Constant), X.

Dengan demikian nilai hasil belajar sebesar 32,8\% dipengaruhi oleh disiplin belajar, sedangkan $67,2 \%$ hasil belajar 
dipengaruhi faktor lainnya, seperti motivasi, minat, kecerdasan, faktor keluarga, faktor lingkungan, dan lain-lain.

\section{Pembahasan}

Hasil penelitian dari data yang telah diperoleh serta di analisis mengenai disiplin belajar dan hasil belajar yang diambil pada mata pelajaran Akidah Akhlak di Madrasah Aliyah Miftahul Huda Cipayung Bogor tergolong baik. Untuk disiplin belajar dengan mean 68,20 terletak pada interval 66 - 72 berjumlah 29 (52,73\%) responden dalam kategori baik, dan untuk hasil belajar dengan mean 82,98 , terletak pada interval 80-88 sebanyak 55 responden dalam kategori baik, karena sudah mencapai KKM sebesar 80. Uji prasyarat untuk menganalisis data menggunakan uji normalitas dan linieritas. Uji normalitas digunakan dengan uji liliefors, adapun hasil pengujian liliefors variabel disiplin belajar adalah Lhitung < Ltabel $(0,0117<0,1194)$, maka H0 ditolak, artinya data populasi terdistribusi normal. Uji liliefors selanjutnya untuk variabel hasil belajar siswa mata pelajaran Akidah Akhlak, dengan hasil Lhitung< Ltabel $(-0,0082<0,1194)$, maka H0 ditolak berarti data populasi terdistribusi normal. Pengujian prasyarat analisis data selanjutnya adalah uji linearitas menggunakan regresi sederhana.Dalam uji ini ditentukan bahwa signifikansi sebesar $5 \%(0,05)$, diketahui bahwa sig linearity $(0,000)<$ nilai signifikansi $(0,05)$, dan sig deviation from linearity $(0,659)>\alpha(0,05)$. Berdasarkan dua pernyataan tersebutdisimpulkan bahwa disiplin belajar dan hasil belajar memiliki hubungan yang linear dan signifikan.

Selanjutnya analisis korelasi product moment menghasilkan rxy $=0,573$ dan rtabel untuk $\mathrm{N}=55$ dan taraf signifikansi 5\% yaitu $r=0,266$. Maka rhitung $>$ rtabel $(0,573$
$>0,266)$. Maka H0 ditolak artinya terdapat korelasi yang signifikan antara disiplin belajar dengan hasil belajar. Berdasarkan analisis uji regresi sederhana diperoleh nilai konstanta (a) 63,257 dan nilai konstanta (b) 0,289 , maka persamaan regresi yaitu $\hat{Y}=$ $63,257+0,289$ X karena nilai koefisien (b) bertanda positif $(0,289)$ sehingga hubungan kedua variable berbanding lurus. Artinya semakin tinggi disiplin belajar, semakin tinggi pula hasil belajar siswa. Adapun jumlah setiap tingkatan ketika ditambah yaitu sebesar 0,289.

Setelah uji analisis regresi, dilanjutkan dengan uji signifikansi dan hasil yang diperoleh adalah nilai Fhitung 25,932 dan Ftabel dengan dfreg $=1$, dfres $=53$ adalah 4,03 pada taraf 5\%. Dengan demikian Fhitung > Ftabel $(25,932>4,03)$, sehingga H0 ditolak, dan disimpulkan terdapat pengaruh yang signifikan antara disiplin belajar terhadap hasil belajar siswa. Hasil koefisien determinasi yaitu 0,5732 $=0,328$, dengan demikian nilai hasil belajar siswa sebesar 32,8\% dipengaruhi oleh disiplin belajar, sedangkan $67,2 \%$ hasil belajar siswa dipengaruhi faktor lainnya, yaitu faktor dalam diri siswa maupun faktor luar seperti kecerdasan, minat, motivasi, faktor keluarga, faktor lingkungan dan lain sebagainya.

\section{KESIMPULAN DAN IMPLIKASI}

\section{Kesimpulan}

Hasil analisis signifikansi pengaruh disiplin belajar terhadap hasil belajar pada mata pelajaran akidah akhlak yang di Madrasah Aliyah Miftahul Huda memberikan kesimpulan bahwa ada pengaruh dengan nilai yang signifikan antara kedua variabel yaitu disiplin belajar dan hasil belajar. Hal ini sangat sesuai dengan kriteria pengujian 
korelasi product moment kedua variabel dengan indeks korelasi 0,573 dan rtabel untuk N=55 dan taraf signifikansi 5\% yaitu 0,266 . Dengan demikian rhitung> rtabel $(0,573>0,266)$. H0ditolak, artinya yaitu terdapat korelasi yang signifikan antara disiplin belajar dengan hasil belajar. Pada persamaan regresi $\hat{Y}=63,257+0,289 X$ dikatakan bahwa disiplin belajar dan hasil belajar adalah hubungan yang berbanding lurus, maksudnya meningkatnya disiplin belajar diikuti meningkatnya hasil belajar. Analisis data menunjukkan bahwa Fhitung=25,932 dan Ftabel dengan dfreg=1 dfres $=53$ adalah 4,03 pada taraf 5\%. Dengan demikian Fhitung> Ftabel $(25,932>4,03)$ sehingga H0 ditolak. Hasil koefisien determinasi 0,328, dengan demikian nilai hasil belajar 32,8\% dipengaruhi oleh disiplin belajar, sedangkan 67,2\% hasil belajar dipengaruhi faktor lainnya.

\section{Implikasi}

Guru menjadi figur sentral di sekolah bagi para siswanya, seorang guru hendaklah dengan bijaksana senantiasa siap membantu siswa mengenai kesulitan belajar terutama pada kedisiplinan belajar siswa. Lembaga pendidikan agar dapat menerapkan kebijakan-kebijakan guna menumbuhkan disiplin belajar siswa, salah satunya lebih memperhatikan siswa, mendisiplinkan siswa serta manambah fasilitas untuk menunjang pelajaran sekolah baik melalui aspek pengetahuan, sikap, dan keterampilannya. Siswa hendaknya tidak melalaikan kewajibannya untuk selalu belajar dan selalu menyelesaikan tugastugasnya. Kesulitan dalam belajar sedapat mungkin diselesaikan melalui metode bimbingan atau arahan kepada siapa saja terutama guru di sekolah sehingga tujuan belajar akan tertuju dengan baik.

\section{DAFTAR PUSTAKA}

Arifin Z. 2012. Penelitian pendidikan: metode dan paradigma baru. Remaja Rosdakarya, Bandung.

Bisri $\mathrm{H}$ dan M Ikhsan. 2015. Penilaian otentik dengan teknik di Sekolah Dasar. Jurnal Sosial Humaniora 6 (2).

Departemen Agama RI. 2004. Al-Qur'an dan terjemahnya. Mekar Surabaya, Surabaya.

Departemen Pendidikan Nasional. 2008. Kamus Besar Bahasa Indonesia Pusat Bahasa. Gramedia Pustaka Utama, Jakarta.

Imron A. 2012. Manajemen peserta didik berbasis sekolah. Bumi Aksara, Jakarta.

Jihad A dan Haris A. 2012. Evaluasi pembelajaran. Multi Pressindo, Yogyakarta.

Prihatin E. 2011. Manajemen peserta didik. Alfabeta, Bandung.

Sanjaya W. 2010. Kurikulum dan pembelajaran. Kencana Prenada Media Group, Jakarta.

Sudjana N. 2009. Penilaian hasil proses belajar mengajar. Remaja Rosdakarya, Bandung.

Sugiono. 2003. Metode penelitian administrasi. Alfabeta, Bandung.

Suryabrata S. 1998. Psikologi pendidikan. Raja Grafindo Persada, Jakarta.

Supardi. 2012. Aplikasi statistika dalam penelitian. Ufuk Press, Jakarta.

Susanto A. 2013. Teori belajar dan pembelajaran. Kencana Prenada Media Group, Jakarta.

Syafruddin. 2005. Hubungan antara disiplin belajar dan perhatian orang tua dengan hasil belajar bahasa Indonesia SMA PGRI Sungguminasa kabupaten Gowa. Jurnal Edukasi Pemikiran dan Penelitian Pendidikan 6(2). 